\title{
A Descriptive Study on Character of Non-Formal Education Students
}

\author{
Elizon Nainggolan ${ }^{1}$, Nasib Tua Lumban $\mathrm{Gaol}^{2}$, Edidon Hutasuhut ${ }^{2}$, Feriyansyah ${ }^{2}$ \\ \{e.nainggolan@gmail.com, nasib.tualbngaol@gmail.com, edidon.h@gmail.com, \\ feriyansyah@gmail.com\} \\ Department of Non-Formal Education, State University of Medan, Medan ${ }^{1}$ \\ Department of Christian Religious Education, Anugerah Sinagoge Medan Theological Seminary, \\ Medan ${ }^{2}$
}

\begin{abstract}
Character is very necessary for university students. However, many of the students show poor performance due to their character problems. The purpose of this research was to describe how character of non-formal education students while studying at University. There were 265 undergraduate students as research population. After determining sample randomly, out of 120 students who participated in this study, there are four main characters performed by non-formal students consist of: (1) lack of creative mind in learning and socializing with other friends; (2) plagiarism while conducting assignments; (3) Laziness to comprehending text book and journal; (4) undisciplined to study. Therefore, lecturers should more engage students to take a part seriously in the learning process in order to build students' character. Further study may consider investigating how to solve non-formal students' character.
\end{abstract}

Keywords: University students, character problems, quantitative research.

\section{Introduction}

Improving the quality of education in Indonesia is always conducted by solving various problems which are related to character. The character becomes very important because through the character individual may be more maximal in developing his/her potential and more beneficial for the surrounding environment or society and country. Particularly, the term "revolusi mental" is as an indication that Indonesian government is dealing seriously with character in Indonesia. Consequently, Indonesian government focuses on how to develop students' character through education which is started from Early Childhood Education (ECD) to Higher Education (HE).

Character of student in Higher Education environments is in the spotlight and needs to be addressed now. Many behaviors of student are not in accordance with the code of ethics and have broken roles in university. For example, some of students cheat others' works, do copying paste from their friend's works and do project with poor performance. These behaviors lead to the degeneration of student character and student dissatisfaction while studying in university.

Palila (2015) [1] emphasized that character is needed to get someone to pursue and achieve their own individual well-being. Character also leads to mental health. Therefore, while students graduate with lack of character, they only graduated with mediocre grades or 
competencies that are not in accordance with the needs of the job field and societies. Those problems are very serious. Therefore, students as a college product and leader in future should be a solution to existing social or workplace problems.

Santoso (2013) [2] stated that Higher Education is a place to sow, educate and train students to become students with high reasoning, sharp and broad analysis. This is because the college's mission is teaching, research and application of science. Characters in adults like students have indeed been fossilized. Improving the character of students in principle depends on the models seen around them. So, anyone in his or her environment can be a reference for him or her to behave and act.

\subsection{Character and University Students}

The term character came from the Greek language which is etymologically derived from the word "karasso", meaning "blueprint", the basic format, fingerprints such as fingerprints [3]. According to Diponegoro (2010) [4] character is a personality that is evaluated based on certain values and norms. Therefore, a person who behaves dishonest, Cruel or Greedy said to be a person of character ugly, while those who behave honestly prefer to say as man of noble character [5]. The character is someone's personality and behavior. Individual who has good or superior character always tries to do the best things to God Almighty, self, others, the environment, nation and state and the international world in general by optimizing his potential (knowledge) and accompanied by his awareness, emotions and motivations (his/her feelings).

According to Curriculum Center of Ministry of Education of the Republic of Indonesia (2010) there are 18 values for character that originally derived from religion, Pancasila, culture and the purpose of national education, namely: (1). Religious: Attitudes and behaviors that are obedient in carrying out the teachings of the religion he adheres to, tolerant of the implementation of other religious services, and live in harmony with other religions (2) Honest: Behavior based on efforts to make himself as a person who can always be trusted in words, actions, and work. (3) Tolerance: Attitudes and actions that respect differences in religion, ethnicity, ethnicity, opinions, attitudes and actions of others that are different from themselves (4) Discipline: Actions that show orderly behavior and comply with various provisions and regulations (5) Work hard: Actions that show orderly behavior and comply with various rules and regulations. (6) Creative: Thinking and doing something to produce new ways or results from something that has been owned (7) Independent: Attitudes and behaviors that are not easily dependent on others in completing tasks (8) Democratic: How to think, behave, and acting that assesses the rights and obligations of himself and others (9) Curiosity: Attitudes and actions that strive to find out more deeply and broadly from what he learns, sees, and hears. (10) Nationality: Way of thinking, acting and being mindful that places the interests of the nation and the State above the self and group interests his group; (12) Appreciating Achievement: Attitudes and actions that encourage him to produce something useful for the community, and recognize, and respect the success of others. (13) Friendly / Communicative: Attitudes and actions that encourage him to produce something useful for the community, and acknowledge, and respect the success of others. (14) Love of Peace: Attitudes and actions that encourage him to produce something useful for the community, and acknowledge, and respect the success of others. (15) Love of Reading: The habit of providing time to read various readings that give virtue to him (16) Caring for the Environment: Attitudes and actions that always strive to prevent damage to the surrounding natural environment, and develop efforts to repair the natural damage that has occurred (17) Social Care: Attitudes and actions that always want to help others and people in need. (18) 
Responsibilities: Attitudes and behavior of a person to carry out their duties and obligations, which they should do, to themselves, society, environment (natural, social, and cultural), the State and God Almighty.

In the context of higher education, the character that should be owned by students can consist of honesty, discipline, diligence, creativity, independence, curiosity, appreciation, and caring. For example, discipline can be shown by the habit of attending on time, getting used to obey the rules that have been mutually agreed upon, getting used to gathering tasks on time. Curiosity characters with indicators reading the language before the lecture starts, are active in learning [6]. However, by looking at the many phenomena that occurred toward student's behavior in university environment, it is necessary to study, specifically, the character of students. The research question in this study is how are the characteristics of Non-Formal Education Students in State University of Medan? This study aimed to find out about the character of Non-Formal Education Students during studying at the State University of Medan.

This research provides both theoretical and practical benefits. Theoretically, this study contributes to filling in the gab on character, particularly, Non-Formal Education Students. Some research on student's character are solely in certain departments, such as psychology students [1] and accounting education students [7]. Based on researchers' knowledge, it was difficult to find study on non-formal education character. Thus, this research may be the first study conducted that may contribute to literature on the study of Non-Formal Students' Character. Practically, this research is useful to the department of Non-Formal Education, State University of Medan and may be to other universities because this study provides some character problems of university students that took place in university environment.

\section{Methodology}

This research is descriptive quantitative which involved one variable solely [8]. Data collected from participants through questionnaire. All participants involved in this study were university students from the department of Non-Formal Education at the State University of Medan. Development of instruments was carried out by examining theories and previous research related to character. In addition, the research instrument was also developed based on observations and interviews conducted by researchers with Non-Formal Education Students. After testing the validity of the instrument to some experts, the four statements were used as instrument to collect data.

The research instrument was as the following statements: (1) lack of creative mind in learning and socializing with other friends; (2) plagiarism while conducting assignments; (3) Laziness to comprehending text book and journal; (4) undisciplined to study. To evaluate the responds of participants on those statements, the answer choices were provided consisting of "Yes" or "No". After data collected by the instrument, those data analyzed using descriptive analysis techniques use SPSS 20 for Windows..

\section{Result and Discussion}

There were 120 Non-Formal Students involved in this study who were selected by simple random sampling technique that forty-eight $(40 \%)$ of the respondents were male, while 72 
$(60 \%)$ were females. According to the result of research, it can be described on the character of Non-Formal Education as shown in the Table 1.

Table 1. Response of Participants

\begin{tabular}{lcc}
\hline \multirow{1}{*}{ Statements } & \multicolumn{2}{c}{ Responses } \\
\cline { 2 - 3 } & Yes & No \\
& $\mathrm{N}(\%)$ & $\mathrm{N}(\%)$ \\
\hline Lack of creative mind in learning and socializing with other friends & $80(66.67)$ & $40(63.33)$ \\
Plagiarism while conducting assignments & $75(62.50)$ & $45(37.56)$ \\
Laziness to comprehending text book and journal & $87(72.50)$ & $33(27.50)$ \\
Undisciplined to study & $73(60.83)$ & $47(39.17)$ \\
\hline
\end{tabular}

In Table 1 seen in general, most of the students agreed that they conducted such as bad behavior while studying at university. Those behaviors have negative impact on students' performance in future. The situation indicates that improving student learning, especially nonformal students are necessary to be done. [6] Santoso (2013) suggested that awareness must be increased so that students are active in learning, so that they have the ability to speak systematically, and the ability to analyze problems. This can encourage the formation of students' character towards a better life. Lecturers must be more active in involving students in the learning process. Thus, Universities in Indonesia must take place in applying character education to students [8].

Furthermore, Soetanto (2012) [9] stated that the application of character education in Universities must be based on five main pillars, namely: (1) Tri dharma of Higher Education which character education can be integrated into education, research and community service activities; (2) College culture or student organizational culture is required for enabling students to be familiar with good character in university; (3) Student activities by doing integration into student activities, including scouts, sports, writing, art, workshops, and events that involve students in the committee system; (4) Student daily activities are done such as daily life habits in the family, dormitory and community; (5) Academic Culture which the value of character education is effectively formed by the existence of a totality of academic culture.

\section{Conclusion}

This study describes how the character of Non-formal Education students while studying in the State University of Medan. Furthermore, based on the results of the study there are four characters, namely: (1) lack of creative mind in learning and socializing with other friends; (2) plagiarism while conducting assignments; (3) Laziness to comprehending text books and journals; (4) undisciplined to study. Therefore, stakeholders, particularly, State University of Medan, need to deal seriously with the character problems that take place toward university students.

Thus, the strengthening of character education for university students is very urgent to be done. Further research on student character needs to be done more in an effort to improve the character of students, especially, non-formal education students. Higher education needs to make routine programs in an effort to improve the character of students, such as training and 
conference. This aims so that the formation of student character can develop naturally and sustainably.

\section{References}

[1] S. Palila, "Analisis Kebutuhan Karakter Mahasiswa Psikologi Fakultas Ilmu Sosial dan Humaniora UIN Sunan Kalijaga Yogyakarta," Humanit. Indones. Psychol. J., vol. 12, no. 2, pp. 105-107, 2015.

[2] J. T. B. Santoso, "Karakter dan Pemahaman Pendidikan Karakter Mahasiswa Pendidikan Akuntansi Melalui Pembelajaran Strategi Belajar Mengajar Berkarakter,” Din. Pendidik., vol. 8, no. 1, pp. 11-25, 2013.

[3] D. K. Albertus, Pendidikan Karakter Strategi Mendidik Anak di Zaman Global. Jakarta: PT. Gramedia Widiasarana Indonesia, 2010.

[4] M. et al Diponegoro, Model Pendidikan Karakter. Jakarta: UI Press, 2010.

[5] R. Saidek, A. R., \& Islami, "Character Issues: Reality Character Problems and Solutions through Education in Indonesia," J. Educ. Pract., vol. 7, no. 17, pp. 158-165, 2016.

[6] E. Santoso, "Peran Pendidikan Karakter dalam Rangka Meningkatkan Kecerdasan Emosi Mahasiswa," Cakrawala Pendidik., vol. 15, no. 1, pp. 1-9, 2013.

[7] M. Ali, M \& Asrori, Motodologi \& Aplikasi Riset Pendidikan. Jakarta: Bumi Aksara, 2014.

[8] R. Susanti, "Penerapan pendidikan karakter di kalangan mahasiswa," Al-Ta lim J., vol. 20, no. 3, pp. 480-487, 2013.

[9] H. Soetanto, Pendidikan Karakter. Malang: Universitas Brawijaya, 2012 